\title{
INTERNATIONAL BUSINESS MANAGEMENT: AGILITY JOURNEY FOR HIGH-TECH COMPANIES ${ }^{\circ} 2019$ ZUBKOVA A. B., RUSANOVA L. D.
}

\author{
UDC 658.5/.3:005:339.9:004 \\ JEL: M16: M54: M15
}

Zubkova A. B., Rusanova L. D. International Business Management: Agility Journey for High-Tech Companies

The purpose of the article is the development of recommendations for the business maturity determination and measurement in the implementation of the agile approach for high-tech companies. Methods of analysis of documents, observation, personal and in-depth interviews, case studies have been used in the research. The findings of the research: Business Agility Journey has been suggested for defining the state of the maturity of the company and conducting express diagnostics of agility. Agile Project Management Journey has been developed for the identification of weaknesses by the companies in the path to agility, as well as for the determination of events for the transition from the traditional to the agile approach. Personal Agility Checklist has been designed for testing the soft skills of employees for the presence of the agile mindset. Research limitations include the study of the maturity of companies in the IT industry. Practical implications are based on the use of suggested Agility Journeys in defining the state of maturity and main problems on the transition path. Also, Personal Agility Checklist will help to check the agility of the future employees. The originality of the article is based on the uniqueness of the Agility Journey that has been developed for the first time. Further research on this topic should be focused on the development of an agile mindset as a prerequisite for the provision of agility in the company. Keywords: international business management, business agility, high-tech companies, Agile Maturity Models (AMMs), Agile Project Management, Business Agility Journey, Agile Project Management Journey, Personal Agility Checklist.

DOI: https://doi.org/10.32983/2222-4459-2019-12-370-383

Fig.: 8. Tabl.: 5. Bibl.: 37 .

Zubkova Alina B. - PhD (Economics), Associate Professor, Associate Professor of the Department of International Business and Finance, National Technical University «Kharkiv Polytechnic Institute» (2 Kyrpychova Str., Kharkiv, 61002, Ukraine)

E-mail: zubkova.alina@gmail.com

ORCID: https://orcid.org/0000-0002-4478-181X

Researcher ID: https://publons.com/researcher/3273112/alina-zubkova/

Rusanova Lolita D. - Graduate Student of the Department of International Business and Finance, National Technical University "Kharkiv Polytechnic Institute» (2 Kyrpychova Str., Kharkiv, 61002, Ukraine)

E-mail: Iolarusanova123@gmail.com

УДК 658.5/.3:005:339.9:004 JEL: M16: M54: M15

зубкова А. Б., Русанова Л. Д. Управління міжнародним бізнесом: Agility Journey для високотехнологічних компаній

Метою статтіє розробка рекомендацій щодо визначення та вимірювання зрілості бізнесу при впровадженні еджайл-підходу для високотехнологічних компаній. у дослідженні використовуються методи аналізу документів, спостереження, особистого та глибинного інтерв'ю та кейс-стаді. Розроблено Business Agility Journey для визначення стану зрілості компанії та проведення експрес-діагностики еджайльності. Agile Project Management Journey було розроблено для визначення компаніями своїх слабких сторін, а також заходів для переходу від традиційного до еджайльного підходу. Personal Agility Checklist був створений для перевірки «гнучких навичок» (soft skills) співробітників на наявність гнучкого мислення (agile mindset). Обмеження досліджень включають вивчення зрілості компаній IT-галузі. Практична значущість грунтується на використанні запропонованих Agility Journeys для визначення стану зрілості та основних проблем на шляху переходу. Також Personal Agility Checklist допоможе перевірити еджайльність майбутніх працівників. Оригінальність статті базується на унікальності Agility Journey, яка була розроблена вперше. Подальші дослідження на цю тему доцільно зосередити на розвитку гнучкого мислення як передумови забезпечення еджайльності в компанії.

Ключові слова: управління міжнародним бізнесом, еджайльність бізнесу, високотехнологічні компанії, моделі зрілості еджайл (АМM), управління проектами еджайл, Business Agility Journey, Agile Project Management Journey, Personal Agility Checklist.

Рис.: 8. Табл.: 5. Бібл.: 37.

Зубкова Аліна Болеславівна - кандидат економічних наук, доцент, дочент кафедри міжнародного бізнесу та фінансів, Національний технічний університет «Харківський політехнічний інститут» (вул. Кирпичова, 2, Харків, 61002, Україна)

E-mail: zubkova.alina@gmail.com

ORCID: https://orcid.org/0000-0002-4478-181X

Researcher ID: https://publons.com/researcher/3273112/alina-zubkova/
УДК 658.5/.3:005:339.9:004 JEL: M16: M54: M15

Зубкова А. Б., Русанова Л. Д. Управление международным бизнесом: Agility Journey для высокотехнологичных компаний

Целью статьи является разработка рекомендаций по определению и измерению зрелости бизнеса при внедрении эджайл-подхода для высокотехнологичных компаний. В исследовании используются методы анализа документов, наблюдения, личного и глубинного интервью, метод кейсов. Разработана Business Agility Journey для определения состояния зрелости компании и проведения экспресс-диагностики эджайльности. Agile Project Management Journey была разработана для определения компаниями своих слабых сторон, а также мероприятий по переходу от традиционного к эджайльному подходу. Personal Agility Checklist был создан для проверки «гибких навыков» (soft skills) compудников на наличие гибкого мышления (agile mindset). Ограничения исследований включают изучение зрелости компаний IT-отрасли. Практическая значимость основывается на использовании предложенных Agility Journeys для определения состояния зрелости и основных проблем на пути перехода. Также Personal Agility Checklist поможет проверить эджайльность будущих работников. Оригинальность статьи базируется на уникальности Agility Journey, которая была разработана впервые. Дальнейшие исследования на эту тему целесообразно сосредоточить на развитии гибкого мышления как предпосылке обеспечения эджайльности в компании.

Ключевые слова: управления международным бизнесом, эджайльность бизнеса, высокотехнологичные компании, модели зрелости эджайл (АМM), управление проектами эджайл, Business Agility Journey, Agile Project Management Journey, Personal Agility Checklist.

Рис.: 8. Табл.: 5. Библ.: 37.

Зубкова Алина Болеславовна - кандидат экономических наук, дочент, доцент кафедры международного бизнеса и финансов, Национальный технический университет "Харьковский политехнический институт» (ул. Кирпичёва, 2, Харьков, 61002, Украина)

E-mail: zubkova.alina@gmail.com

ORCID: https://orcid.org/0000-0002-4478-181X

Researcher ID: https://publons.com/researcher/3273112/alina-zubkova/ 
Русанова Лоліта Дмитрівна - магістрантка кафедри міжнародного бізнесу та фінансів, Національний технічний університет "Харківський політехнічний інститут» (вул. Кирпичова, 2, Харків, 61002, Україна)

E-mail: lolarusanova123@gmail.com
Русанова Лолита Дмитриевна - магистрантка кафедры междуна родного бизнеса и финансов, Национальный технический университет "Харьковский политехнический институт» (ул. Кирпичёва, 2, Харьков, 61002, Украина)

E-mail: lolarusanova123@gmail.com
$\mathrm{I}$ nternational business management is a rather difficult process. The main reason for this is certain constraints, e. g., differences in culture, corporate culture, and understanding of business among countries. Currently, all successful companies transform their business in international. In Ukraine, high-tech companies, or in other words IT companies, take one of the first places in business. They are constantly evolving. According to the Kharkiv IT Research Report 2019, "In 2018, Kharkiv IT companies paid ca. 6.4 billion UAH of tax revenues, $45 \%$ of which went to the local budget" [1]. Because of the increased popularity of the IT industry, the problem of management of IT companies arises. Management of projects in these companies can be implemented by the traditional (Waterfall) approach or by the Agile approach. At present, Agile Project Management is gaining popularity among methods of project management.

Based on the findings of our previous researches, the definition of Agile Project Management has been developed. Thus, Agile Project Management (APM) is an approach to project management which divides the project process into small cycles to respond quickly to the changes in the business environment [2]. The term derives from the core characteristics of agility. As Martin Christopher stresses out, agility is the ability of an organization to respond rapidly to changes in demand both in terms of volume and variety [3].
Usually, companies switch to Agile Project Management from the traditional approach, which is called Waterfall. When an organization decides to switch to agility it faces many problems. One of the reasons when an organization decides to do so is the implementation of Scrum. The Scrum Surveys at Yahoo!, in which $71 \%$ of its workers took part, revealed that after the implementation of Scrum almost all respondents had positive feelings (Fig. 1) [4].

0 witching to Agile from Waterfall is based on the maturity models. The issues concerning Agile Maturity Models have been widely reflected in studies in the field of management. Agile Maturity Model is a tool that helps a company to identify its current position and gives an understanding of how to improve its activities to achieve agility. Many foreign scientists have made their contributions to defining the main stages of maturity, namely, C. Patel and M. Ramachandran, J. Humble and R. Russell, N. Warren and others [5-7]. Moreover, a number of organizations, such as Harman, suggested maturity models [8]. All these contributions are significant in defining the stages of maturity of an organization. $\mathrm{Al}$ most all of them highlight 5 main stages of maturity, but, according to some authors, zero or -1 levels also exist. A better understanding of their classifications gives a better understanding of the current state of the organization.

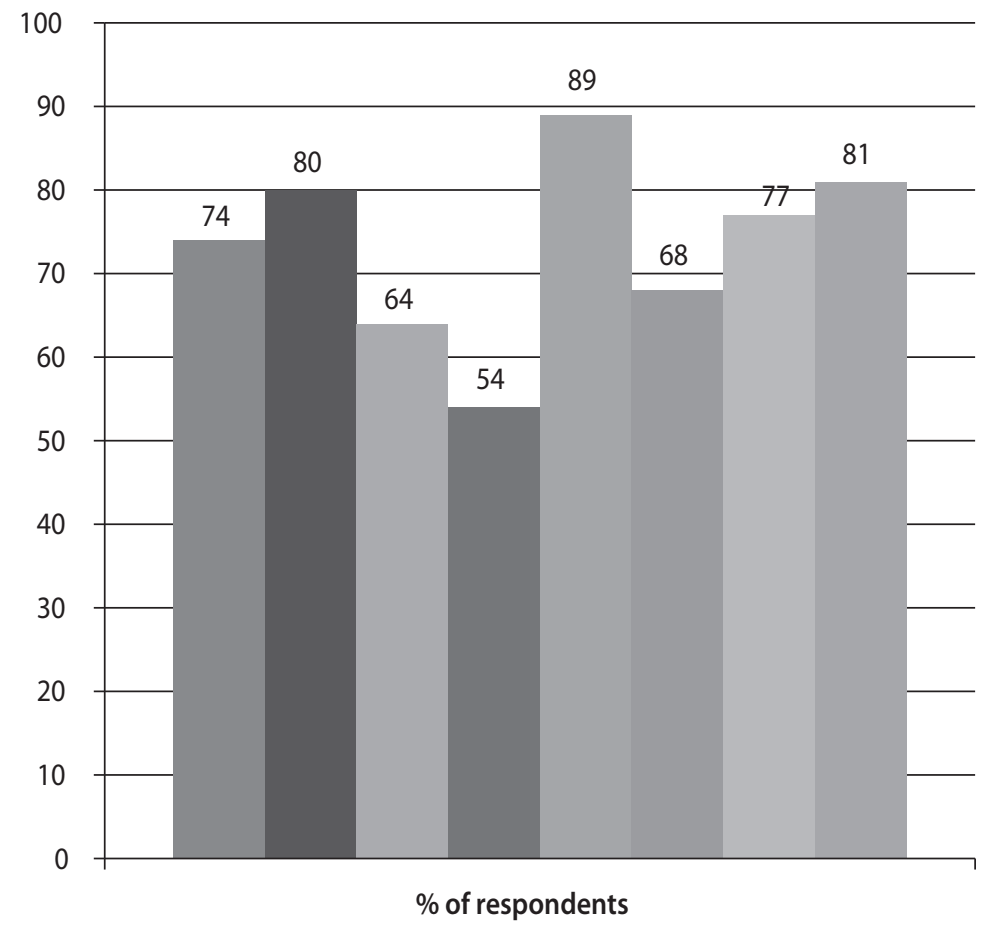

— Scrum impoved 30day productivity

- Scrum helped clarify team goals

Scrum improved the business value of their product at the 30-day mark

- Scrum improved overall quality

- Scrum helped collaboration and cooperation with the team

- Scrum helped reduce the amount of time wasted

- Have positive feelings concerning Scrum

- Wanted to continue using Scrum

Fig. 1. Statistics based on Scrum Survey 
With the help of methods of observation and using expert opinion from Scrum practitioners in the LinkedIn group, the following problems have been defined:

1. Issues of cultural differences, effective communication, pair programming arise for distributed teams. Cross-cultural differences influence the way team members work together.

2. Many disputes appear as regards the right time for the Daily Scrum, Sprint Review. It's hard to find the time convenient for everybody, especially it concerns the teams that are distributed and have a difference in time.

3. Some people are resistant to change. They like stability and don't want to change anything because of the fear they have.

4. The main questions that appear are associated with the agile mindset and how to switch to Agile from Waterfall [9].

工n n connection with the popularity of the Agile Methodology of Scrum, there arise the main problems of determining the state of an organization, understanding how the transformation happens, how to carry out the transition to Agile from Waterfall. The existing problems in approaches to project management in terms of organization of business processes and agile mindset of people also have been identified. Hence, this article aims to provide some answers concerning this topic.

The purpose of the article is the development of recommendations for the business maturity determination and measurement in implementing the Agile approach by high-tech companies.

Based on the problem statement and purpose of this research the following hypotheses have been outlined.

Hypothesis 1: Business Agility Journey can be defined and measured.

Hypothesis 1.1: Levels of maturity of companies in agile practices can be identified (Fig. 2).

To carry out agility diagnostics it's necessary to understand what metrics exist and how to measure business processes with their help. Based on this information, a sub-hypothesis has been constructed:
Hypothesis 1.2: It is possible to conduct an indepth diagnosis of the agility of a company (see Fig. 2).

Agile Project Management is constantly gaining popularity. Thus, companies have difficulties in switching to agile from the traditional approach. Based on this, the next hypothesis has been suggested:

Hypothesis 2: Agile Project Management Journey can be defined (see Fig. 2).

It's necessary to achieve agility in every sphere of the company's activities. Thus, except for ensuring agile business processes in the organization, people must be also agile, or in other words, have an agile mindset. The third hypothesis has been proposed for understanding the connection of maturity of the organization with an agile mindset.

Hypothesis 3: Personal Agility can be checked (see Fig. 2).

Research methods. Proceeding from the necessity of defining the level of maturity of the company, it has been decided to look at the existing Agile Maturity Models (AMMs). When studying these models, the article of Mike Hoogveld and John Koster was analyzed [10]. In the course of their research, the authors found 52 AMMs. Thus, these 52 AMMs together with 2 other models, namely, Agility Health Radar, Agile Adoption and Improvement Model, will be considered in our investigation. The analysis of models has shown the need for filtration. It will be conducted by choosing the models with the word "maturity" with consideration for the additional 2 important models. Therefore, 15 AMMs will be studied. It is necessary to consider key business processes at each level of maturity. Hence, we will divide the AMMs into 2 groups: Scaling Model and Transition from Waterfall to Agile. The main focus will be on the second type of models. They will be further divided into 4 groups, based on the difference in processes at each level of maturity. After defining the main business processes at each maturity level, different states of the organization are needed to be briefly described. The method of analysis of documents using content analysis techniques will be used while conducting this part of the research.

\section{Business Agility Journe}

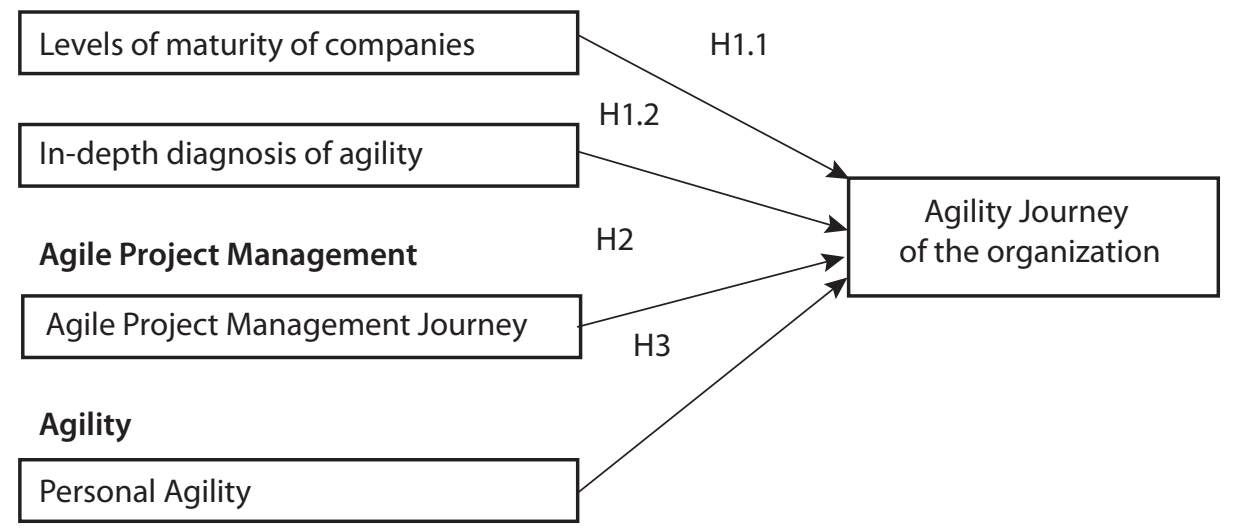

Fig. 2. The Logic of the Research 
A ccording to the hypotheses of the research, it's necessary to conduct an in-depth diagnosis of the agility of a company. To measure the level of maturity of a company, the method of in-depth interview of the company will be used in the research. A list of questions is based on the data from the Agility Health Radar and questions concerning Scrum roles, KPIs. Also, correspondence of business processes to agile principles will be considered. Most useful Agility Measurement Models will be checked for conformity to agile principles. During this process, Business Agility Model will be chosen as the most suitable, and thus the main measurements for performing the diagnosis will be defined. Thereby, it will be necessary to identify what it makes sense to check, how agility diagnostics is conducted and how to check the state of an organization by key business processes at each level of maturity. Methods of personal interview and observation will be used when carrying out this part of the research.

To carry out the transition of the company from Waterfall to Agile, the roadmap will be developed using the method of case studies. Case studies are constructed based on the observations, analysis of documents and personal in-depth interviews. IT companies from Ukraine, Sweden, and the USA will be considered. The choice of these countries is based on the following: the share of Kharkiv IT-cluster's exports to the USA is 74\%; Sweden is the birthplace of many IT startups, such as Spotify, and also it is the biggest destination in Europe for Ukraine's export. Consideration of the companies will help in defining weaknesses which they have.

Also, it's necessary to understand that for companies to be agile it's not enough to make their processes agile; the agility of a person plays a rather important role too. That's why with the help of the method of document analysis and previous studies in the field of Human Resources Management and Employee Selection, in particular, the agile mindset will be developed.
Normally organizations want to switch from Waterfall to Agile to make the process of project management more flexible and fast. To perform this transition, the following hypotheses will be thoroughly considered:

Hypothesis 1: Business Agility Journey can be defined and measured. Hypothesis 1.1: Levels of maturity of companies in agile practices can be identified.

54 Agile Maturity Models (AMMs) have been analyzed. The logic of filtration is described in the research methodology (see above). Briefly, to identify main models for the research, Agile Models with the word "maturity" were considered. These AMMs were divided into the following categories: Agile scaling and transition from Waterfall to Agile.

The scaling model developed by Martin Proulx is called the Agile Maturity Model [11]. It shows the transition of agile from the team level to the management level through the department, business and PM levels. This model consists of 5 levels (Tbl. 1$)$.

$\mathrm{T}$ The second type of models shows the transition from Waterfall to Agile. The main processes of all these models at each level are described in the table below (Tbl. 2). Thus, it's also possible to see not only on which processes the focus is made but also the main points on the transition path. 15 Agile Maturity Models have been researched for defining the main business processes.

The further division of the AMMs into four groups was made based on the characteristics of the main processes at each level of maturity. The first group starts from the establishment of agile properties at -1 level and goes through the communication phase, executable artifacts, and finishes with continuous improvements and learning management. Asif Qumer, Brian Henderson-Sellers, Tom McBride and Jay Packlick highlighted the levels in [12; 13] in 2007 (Fig. 3). 
Combination of AMMs by the focus on key business processes at each level

\begin{tabular}{|l|l|l|}
\hline Level & \multicolumn{1}{|c|}{ Focus on key business processes } & \multicolumn{1}{c|}{ Short description } \\
\hline 1 level & Unrepeatable processes, inconsistent practices & Team culture is in the waterfall \\
\hline 2 level & Project Planning, Requirements Management & Teams follow some ideas of agile development \\
\hline 3 level & $\begin{array}{l}\text { Customer Relationship Management, delivering working } \\
\text { products or SW frequently }\end{array}$ & The team is in the middle of the waterfall and agile \\
\hline 4 level & $\begin{array}{l}\text { Project Management, sustainable pace, engineering ma- } \\
\text { turity, self-organization team }\end{array}$ & The team follows many ideas of agile \\
\hline 5 level & $\begin{array}{l}\text { Project Performance Management, process improvement, } \\
\text { innovation }\end{array}$ & $\begin{array}{l}\text { Established working agile development/ and combi- } \\
\text { nation with lean and other approaches }\end{array}$ \\
\hline
\end{tabular}

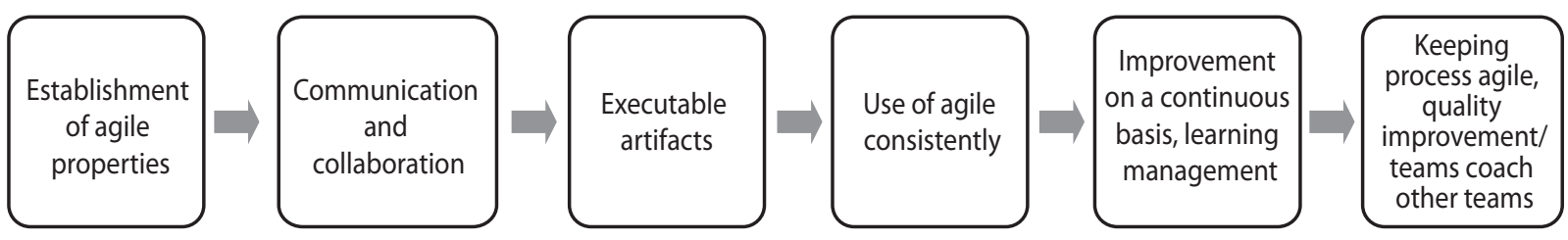

Fig. 3. Transition from the basics of Agile to the spreading of Agile across the organization

The second group to which many AMMs belong starts from unrepeatable, poorly controlled processes, continues with Project Planning, Requirements Management, Customer Relationship Management, and sustainable pace, and ends up with process improvement. Patel C. and Ramachandran (2009); Jez Humble and Rolf Russell (2009); M. Yin A., Figueiredo S., da Silva M. M. (2011); Greger Wikstrand (2014) were supporters of the second group (Fig. 4) [14; 15].

The third group starts from no process improvement goals, then obtaining of agile certification by team members. At the third level, the focus is on agile strategies, then the self-organized team, and, at the last level, techniques are adopted not only from agile but also traditional, lean and other paradigms. Scott Ambler (2011) and Daniel Tousignant (2018) suggested the following levels of the AMM (Fig. 5) [16].

The fourth group shows how teams start from an application on an ad hoc basis and through consistent practices finish with development on cadence and release on demand scaled principle. Harman (2017) and Nigel Warren (2019) were supporters of this model [7; 8] (Fig. 6).

For checking Hypothesis 1 and based on the research we have developed Business Agility Journey (Fig. 7). It shows the main processes at each level of maturity.

B usiness Agility Journey starts from the Chaos. It is the level at which the organization doesn't have consistent practices. The second stage consists of the Requirements Management phase. After this stage,

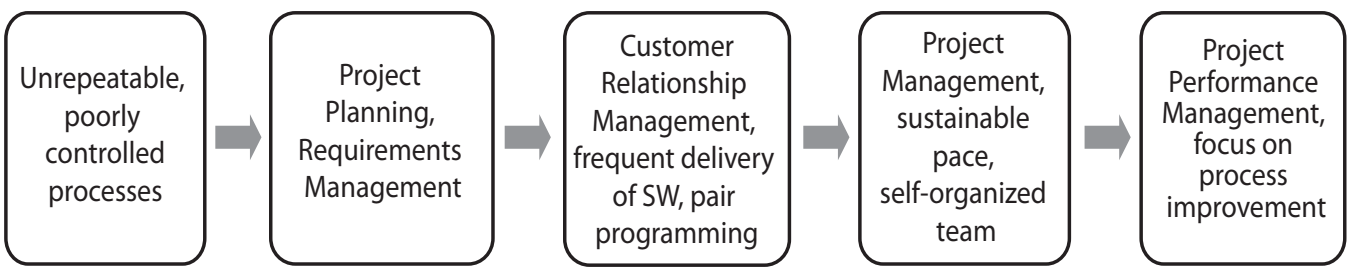

Fig. 4. Transition from unrepeatable processes to focus on process improvement

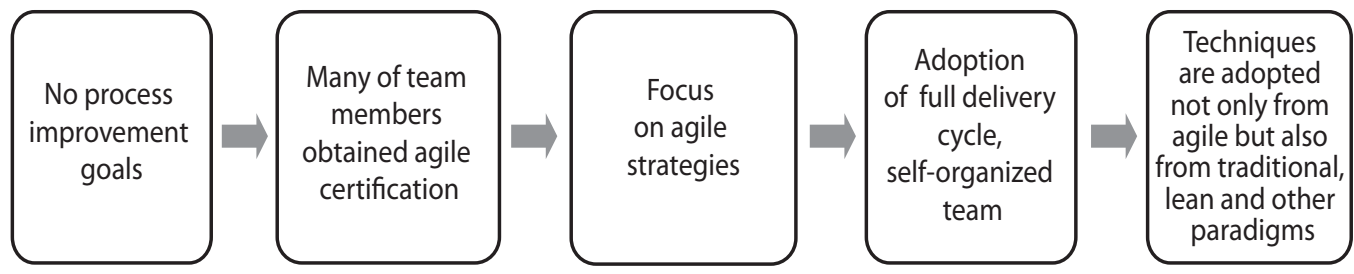

Fig. 5. Transition from chaos to consistent adoption of the agile and other approaches 


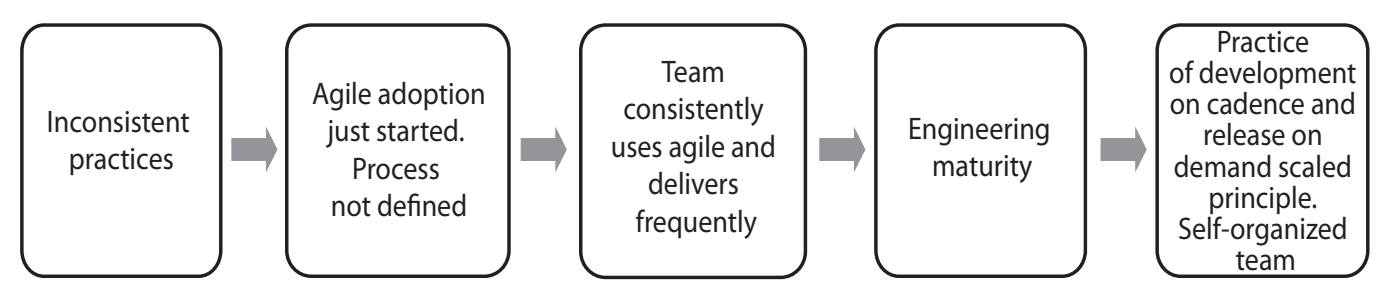

Fig. 6. Transition from inconsistent practices to scaled principles

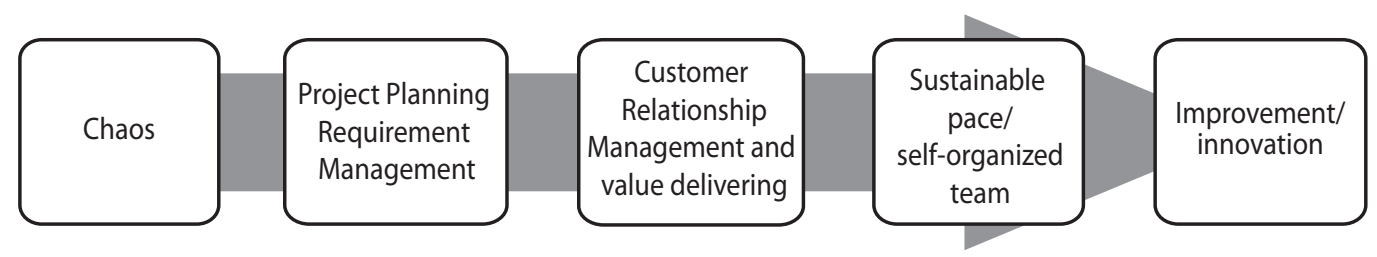

Fig. 7. Business Agility Journey

the main focus must be on customers and delivering value. At the fourth stage, the team must be self-organized and all practices must be consistent. And at the fifth stage, constant improvement and innovation occur. Business Agility Journey has been developed based on the generalization of key business processes at each level of the maturity of the company and allows to simplify the perception and use of the maturity models, as well as to conduct rapid diagnosis of the maturity level of the company.

Hypothesis 1.2: It is possible to conduct an indepth diagnosis of the agility of a company.

The general approach to defining the position of the company in Business Agility Journey can be applied for conducting express diagnosis of agility. Team Health Radar, which has been developed by Agility Health organization together with issues concerning roles in the team and how the team works in the agile environment, can show the level of maturity of the organization [17]. Also, the correspondence of business processes to Agile principles shows the state of the company.

Models based on the correspondence to Agile principles describe main business processes to make an understanding of the maturity of the organization visible. Many models have been researched and 4 most useful chosen (Tbl. 3). Also, the main variables for measurement were identified based on the Business Agility Model. They correspond to Agile principles.

$\mathrm{H}$ arman Maturity Model is built with consideration for Agile Principles and Agile Key Performance Areas. It consists of 5 levels, starting from Ad-hoc Agile and finishing with Scaled Agile. This Assessment Model is based on the Agile Maturity Model developed by Patel Chetankumar and Muthu Ramchandran from Leeds Beckett University. As this model uses the principles of the Agile Manifesto, it's easy to see which points are measured, but there is no information concerning how to measure each process.

There exist Why-Ability Models (Principles of Agile Manifesto), What-Ability Models (Scrum, XP,
Kanban), and How-Ability Models. Agile Performance Holarchy is a How-Ability model that provides information about the agility of an organization [18]. The model consists of 6 performance circles: Leading, Crafting, Envisioning, Teaming, Affirming, Providing. Each of them consists of some processes. They are estimated by three levels: adopting, transforming and mastering. All circles can be estimated separately by organizations to understand in which direction the organization should evolve. This Model shows processes in which an organization should develop itself as well as gives some ceremonies and techniques to be established for the understanding of the position of the enterprise. Unfortunately, information is not provided for all circles.

$\mathrm{E}$ nterprise Business Agility Model is created by the Agility Health community [19]. It stresses out the following areas: Customer Seat at the Table, Lean Portfolio Management, Org Structure and Design, Agile Framework and Mindset, Leadership and Culture Transition, Make it Stick/Sustain, Technology Agility. This model shows metrics by which some points can be measured. All information is presented in the form of Radar, which is the visualization tool that makes it possible to understand the level of the organization. The main thing that is not so clear in this model is why it also focuses on Lean Portfolio Management. One of the reasons is that Lean Portfolio Management is usually employed in already formed agile organizations.

The Business Agility Model is created by Business Agility Institute and Agility Health community [20]. It represents the main domains in agile transformation. Business Agility is best seen as a continuous and systematic evolution of culture, people, and skills. The main domains are Customer, Relationship, Leadership, Individuals, and Operations. This model helps in going through an Agility Journey. By answering questions of the Business Agility Survey, it's possible to get the Radar which shows which areas should be improved in the future. The main pros of this model are that it shows the level of 


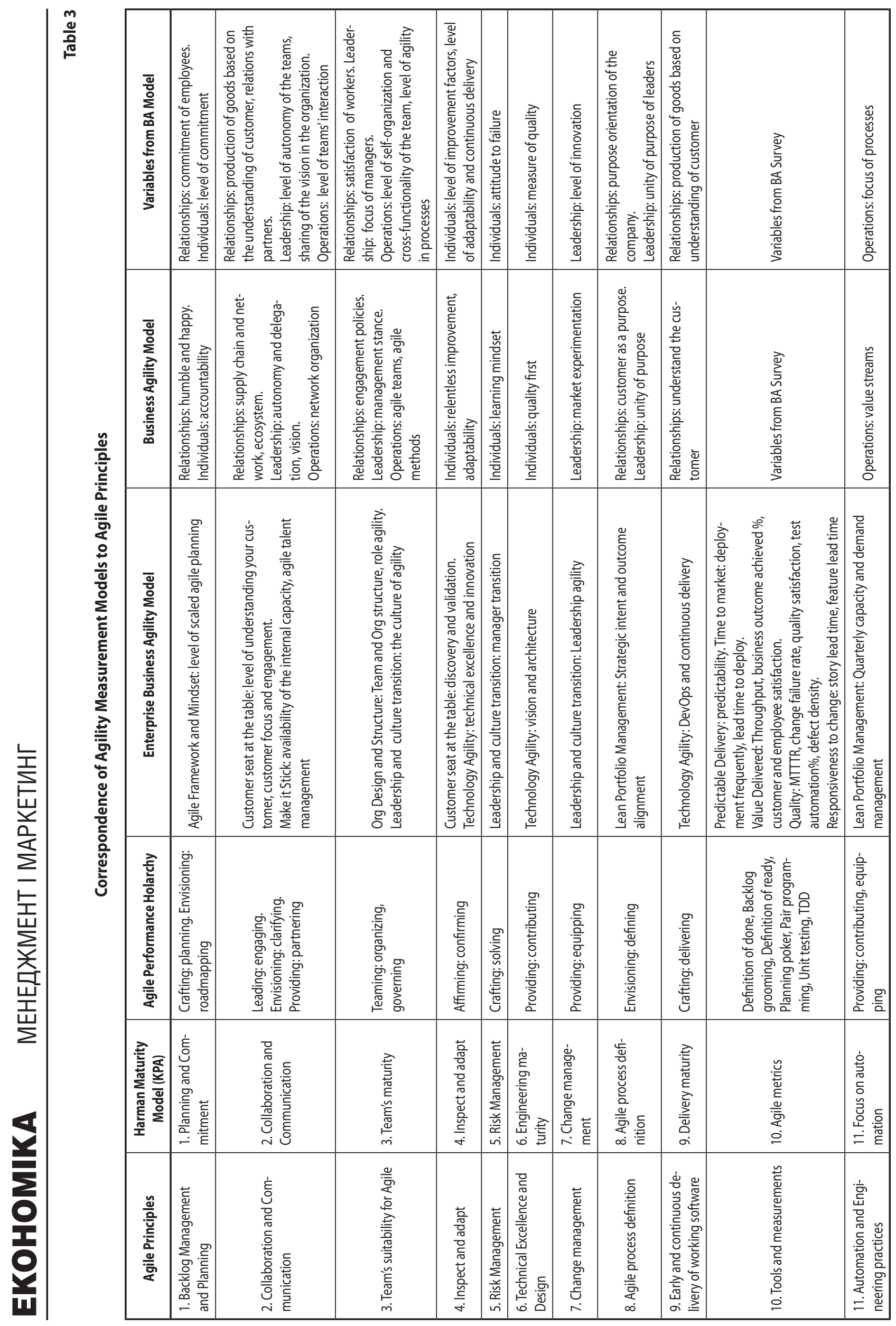


organization in main areas. But it's not so clearly visible that areas of models intersect with Agile Principles.

Based on the comparison of these models, it is seen that Business Agility and Enterprise Business Agility Models show how business processes can help in defining the level of maturity. The general approach to express diagnosis is based on estimation of maturity of the company by Agility Health Radars. But for conducting deep diagnosis, it's necessary to check the correspondence of business processes of the company with agile principles. Also, questions about the roles and responsibilities of employees must be included in determining the state of maturity of the organization.

By using the technique of in-depth interview, it has been revealed that most of the companies in their Business Agility Journey stay at the levels 1-3. Thus, companies don't have complex metrics for measuring the implementation of processes. To conduct this interview, questions concerning variables from Business Agility Model together with those about roles and responsibilities have been used.

In contrast to Hypothesis 1, Hypothesis 0 has been proposed: Business Agility Journey can't be defined and measured. It's possible to assume that there are no approaches to defining the maturity of the organization. It is due to the fact that all organizations are different, and thus it can be rather hard to define processes for each level of maturity. As concerns measuring the maturity of the organization, it can be said that there are no specific metrics for that, so it makes this process rather complicated.

Hypothesis 1 has been proved due to the possibility of the development of Business Agility Journey and the existence of the company agility diagnosis. Based on Business Agility Journey, it's necessary to develop an Agile Project Management Journey. It will help to improve the agility of a company enhancing weak sides of the company.

Hypothesis 2: Agile Project Management Journey can be defined.

$\mathrm{F}$ or constructing Agile Project Management Journey, which is based on the implementation of Scrum, 7 case studies of foreign companies were developed and researched.

\section{CASE STUDY OF YAHOO! (USA)}

Yahoo! is an American web services provider. The company was established in 1994. The number of employees is 8600 . The mission of Yahoo! is to connect people to their passions, their communities, and the world's knowledge. The number of teams that use Scrum is more than 150.

They started from the decision of Scrum implementation because of the issues in planning, project management, release management, and interactions. In the beginning, there were 4 teams which adopted Scrum. The test period was 30 days ( 1 Sprint). The teams were coached by outside Scrum Masters, learned literature on Scrum implementation. The coach session lasted 2 days: $1^{\text {st }}$ - creating an agile mindset, $2^{\text {nd }}-$ teaching teams of Agile principles. During the Scrum implementation, extra work, conflicts, fear, stress, pain, risk of failure, and other things that people ordinarily try to avoid at all costs, appeared. Thus, internal coaches worked on the overcoming of all these things. As it was a test period, teams could stop using Scrum after it was over. The results of the survey showed that after implementing this methodology all teams were satisfied. Thus, more than 150 teams nowadays implement Scrum in the company [21].

\section{CASE STUDY OF THE SWEDISH COMPANY}

This case describes how Scrum is implemented in a company located in Stockholm. It deals with the Scrum adaptation to their firm due to different experiments. The experiment was conducted in the development team of approximately 40 people. The Scrum implementation affected all layers of the company which was trying different size of teams, lengths of sprints, defining "done" for each team, different displays of product backlogs, and sprint backlogs (Excel, Jira, index cards), different strategies for testing, different ways of doing demos, different ways of synchronizing multiple Scrum teams.

The company was in a tough situation with high overtime, severe quality problems, constant firefighting, missed deadlines, etc. They had decided to use Scrum but not fully completed the implementation, which was then conducted correctly with the help of Henrik Kniberg. The reason for that was that people heard about Scrum but didn't understand how to implement it.

Henrik, at his first lectures about Scrum and later as an internal coach, helped the teams to implement Scrum through continuous experimentation. There was not much work related to an agile mindset and fear overcoming because the company wanted changes and was ready for them. Special Scrum surveys were not conducted in the company. The result of the experiment was in implementing Scrum in several teams within one project, Scrum-of-Scrums [22].

\section{CASE STUDY OF ANIART (UKRAINE)}

AniArt is a leader in the implementation of large e-commerce projects. 18 certified workers, 6 certified developers work in this company. AniArt works in the CIS market.

This case study deals with the Scrum implementation in a management system for Academy of Modern Education A+ from the perspective of Project Manager. The Academy is a modern educational center in Kyiv, which includes a school, a kindergarten, and specialized courses. In total, more than a thousand children attend almost 150 different courses at this educational establishment.

The goal was to create a unified information system for the Academy. As a result, it was supposed to receive a program in which teachers and other staff members 
could draw up and change the schedule, keep an electronic journal, notify students of any changes, and parents - of their children's performance. After taking the decision on the implementation of Scrum in the company, the training of the Development Team was carried out by Scrum Ukraine. During the training, mindset of the PO and Team was changed. After each Sprint, there was also internal coaching for the team to be agile all the time during the project. As the company is small, it was enough to implement Scrum in small projects [23].

\section{CASE STUDY OF GAMELOFT (UKRAINE)}

Gameloft was founded in 1999 in Paris with a whole range of games that can be easily downloaded to our mobile phones. The mission of the company is to spread across the globe. The company employs 4,600 people and has 19 offices. Gameloft has 190 games designed for 10,000 smartphones and tablets in 11 languages [24].

The vision and goals of the company are not clear for all workers. Project Planning takes place in the short, medium and long term. All project requirements are always discussed with the client. The client is actively involved in the project. The company develops its products, so PO is the person on the side of the company. Many teams are self-organized. The company does not have a clear methodology because the gaming industry is quite specific. For example, if you do everything according to the Scrum methodology, and as a result the game simply does not start in this case, it is unclear how to call this situation. Scrum roles and artifacts are present.

There was no special training conducted in the company concerning the Scrum implementation. One of the reasons is that the company does not offer any specific training to its workers. Its employees know about methodology from various sources. Concerning roles, Project Manager is Scrum Master and Product Owner. The staff of the company don't know about Agile Mindset and Scrum-of-Scrums.

\section{(UKRAINE)}

\section{CASE STUDY OF SIGMA SOFTWARE}

The history of the company begins in 2002, when Eclipse SP was incorporated. In 2014, the company entered the international market and became known as Sigma Software. The company has 7 offices in Ukraine, representative offices in the USA, Sweden, Poland, Great Britain, Austria, and Australia. Sigma Software has more than 1,000 professionals. The company works with Europe, Ukraine, the USA, and the UAE. Most of its projects are commercial. Sigma Software's mission is to provide first-rate IT services while maintaining a focus on helping clients to achieve their business goals [25].

The vision and goals of the company are not very clear for each employee. Project Planning takes place in the short, medium and long term. All project requirements are always discussed with the client. The client is actively involved in the project. Product Owner is a tech- nology-savvy customer representative. Teams are mostly self-organized. Some company projects use the Agile methodology, some - the Waterfall approach. It all depends on the project and the decision of Project Manager.

There was no special training conducted in the company concerning the Scrum implementation. If, according to Personal Road Map, an employee needs some training, he/she can request it at a Sigma University. Mainly the staff know about the methodology from various sources. Concerning roles, Project Manager is Scrum Master and together with Team Technical Leader execute the role of People Manager. There is internal coaching inside the company for junior specialists. They have mentors who oversee their work and help in executing it if necessary. The company's employees don't know about Agile Mindset and Scrum-of-Scrums.

\section{CASE STUDY OF SOFTSERVE (UKRAINE)}

SoftServe is a leading IT consulting company that provides digital services. SoftServe is one of the largest software developers in Central and Eastern Europe and is one of the three largest outsourcing companies in Ukraine. It was founded in 1993 in Lviv. SoftServe employs 5,000 workers. The company's mission is to deliver the innovation, quality, and speed which customers and their users expect [26].

The vision and goals of the company are clear for employees. Project Planning takes place in the short, medium and long term. All project requirements are always discussed with the client. The client is actively involved in the project. Teams are mostly self-organized. Some projects of the company are based on the Agile methodology, some - on the Waterfall approach. It all depends on the project and the client's decision. The company is customer-focused and value-creating.

There was no special training conducted in the company concerning the Scrum implementation. Mainly, the company's employees know about the methodology from various sources. Concerning roles, there is no PO in the company, Project Manager can obtain Scrum Master Certification, but it is not necessary for the execution of the role. All processes and all the work of the company should be built on the Agile approach. Since the IT sphere is changing very fast, people need to be flexible. As for the agile mindset, special training is not conducted to develop the company. It is believed that people engaged in the sector of information technology should always be ready to change and constantly evolve; otherwise, the work in this field is not for them. In addition to the product delivery department, there are functional units that work iteratively. Thus, it's obvious that the company is quite agile.

\section{CASE STUDY OF DEV-PRO.NET (UKRAINE)}

The company was founded in 1993. Dev-Pro.net is of the American origin. As a result, most projects are related to the US and Canada markets. The company is engaged 
in outsourcing activities. Dev-Pro.net employs 468 people. Its mission is to help tech companies to become industry leaders and create a supportive and challenging environment for team members to fulfill their potential [27].

Everyone in the company knows about its vision and goals. Project Planning takes place in the short and medium-term. In a fast-paced environment, it makes no sense to set goals for more than 1 year. All project requirements are always discussed with the client. The client is actively involved in the project. Teams are mostly self-organized. Some company projects are based on the Agile methodology, some - on the Waterfall approach. It all depends on the project and the client's decision.

The most popular is the Scrum methodology. Large projects use Scrum-of-Scrums, DAD, SAFe, Less frameworks. The company has an understanding of an agile mindset. Project Manager is constantly reminding of the goals of the company and works with each employee. The goals of the company are set by the President of the company. In the interview, they test the flexibility and stress resistance of future employees. After that, employees have an adaptation period of 2-3 months. Usually during this period a mentor provides constant coaching with the worker. During this period, each employee is checked on how he/she fits into the hierarchy of the company.

$\mathrm{B}$ ased on the cases of international companies, Agile Project Management Journey was developed to test Hypothesis 2 (Fig. 8). This helps to define the list of events for the company on its way to agility.
Also, all 7 companies estimated based on the main components of Agile Project Management Journey ( $\mathrm{Tbl} .4)$.

Business Agility Journey in its simplicity allows easing perception for conducting express diagnosis of the company to define its state. Agile Maturity Models were improved by synthesizing the stages at each level of maturity. Based on this, Business Agility Model has been developed. After conducting the aggregation of Agile Maturity Models and based on such models as McKinsey [28] and Sales Funnel [29], Business Agility Journey has been developed.

E ach company has its Journey. It's important to conduct agility diagnosis to determine the state of the company. Business Agility Institute suggests Radars for each component of diagnosis and unique journey based on this. But the cons of Radars are that it's difficult for companies to handle all Radars, metrics, understand the direction to move. Even the consultant doesn't simplify this process. Radars are good for metrics. Processes of Business Agility Journey were measured using Agile Principles. After that, Business Agility Journey could be clarified based on the details of the diagnosis with the help of Agile Measurement Models. Processes of Business Agility Model were compared with Agile Principles and thus it was determined that its correspondence shows the possibility to measure the level of maturity of the company by metrics of the Model. For the first time, Agile Project Management Journey has been developed to conduct a transition from Waterfall to Agile in a more

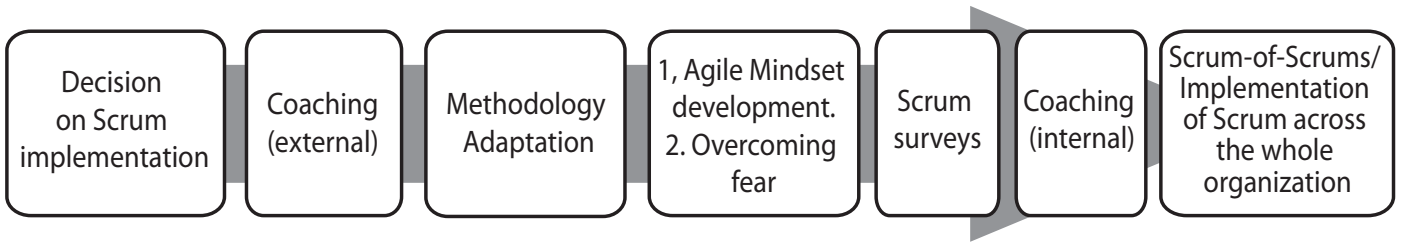

Fig. 8. Agile Project Management Journey

Table 4

Estimation of measures taken by the companies based on the Case Study Results

\begin{tabular}{|l|c|c|c|c|c|c|c|}
\hline \multicolumn{1}{|c|}{ Measures of APM Journey } & Yahoo! & $\begin{array}{c}\text { Swedish } \\
\text { Company }\end{array}$ & AniArt & Gameloft & $\begin{array}{c}\text { Sigma } \\
\text { Software }\end{array}$ & SoftServe & Dev-Pro.net \\
\hline $\begin{array}{l}\text { Decision of Scrum implementa- } \\
\text { tion }\end{array}$ & 5 & 5 & 5 & 5 & 5 & 5 & 5 \\
\hline Coaching(external) & 5 & 5 & 5 & 1 & 1 & 1 & 2 \\
\hline Methodology Adaptation & 5 & 5 & 5 & 4 & 4 & 4 & 4 \\
\hline 1. Agile Mindset development & 5 & 3 & 5 & 1 & 1 & 5 & 5 \\
\hline 2. Overcoming of a fear & 5 & 3 & 5 & 2 & 2 & 5 & 5 \\
\hline Scrum Surveys & 5 & 2 & 2 & 1 & 1 & 1 & 1 \\
\hline Coaching (internal) & 5 & 5 & 5 & 3 & 3 & 2 & 5 \\
\hline $\begin{array}{l}\text { Scrum-of-Scrums / Implementa- } \\
\text { tion of Scrum across the whole } \\
\text { company }\end{array}$ & 5 & 5 & 2 & 2 & 2 & 5 & 5 \\
\hline
\end{tabular}


fast and understandable way. It is based on 1-3 levels of Business Agility Journey. And with regard to the estimation of measures of the companies, main problems were identified, one of them being Agile Mindset development. Based on the PAR competencies of the Agility Health community, Personal Agility obtained further development in our research.

In contrast to Hypothesis 2, Hypothesis 0: Agile Project Management Journey can't be defined, has been proposed. When the company wants to switch to the Agile approach from Waterfall, there must be some way to do so. Agile Project Management Journey was developed based on the research of case studies of international companies. Thus, without conducting analysis and personal interviews the Journey couldn't be developed. In this case, Hypothesis 2 was proved by constructing Agile Project Management Journey, which serves as a road map for a company in order to make the transition.

The results of the estimation of the companies allow compiling a list of events for the transition from one stage to the other.

I n Methodology Adoption box, it is necessary to stress the corporate culture, which has to support the selfinitiative of the employees or team members. The box with Agile Mindset Development and Overcoming the Fear is in the middle of Agile Project Management Journey. And it is the cornerstone for the successful development of agility in employees. The Business Agility Institute notes, "Business Agility requires that individuals are open to learning by doing, continuous learning and personal development as well as being comfortable operating and making decisions in a dynamic and ambiguous environment, free from the fear of failure." "Failure needs to be seen as an opportunity to learn, rather than a failure to do" [30]. These statements are closely connected with Dr. W. Edwards Deming's 14 key principles for Management or 14 points for Management, especially with "8. Drive out fear, so that everyone may work effectively for the company" and " 13 . Institute a vigorous program of education and self-improvement" [31]. This field of study belongs to quality management. The quality culture development [32; 33], as the core of the corporate culture, is the key to overcoming fear and leaning on failures for continuous improvements in the entire organization and continuous value delivery [34] for customers and other stakeholders of the company.

Hypothesis 3: Personal Agility can be checked.

During the investigation of the companies' transition path, the problem of agile mindset arose. Many companies simply don't know what it means or have difficulties with checking it. To be agile, the company should consider such an important component as the agility of a person. Thus, a Hypothesis about Personal Agility has been suggested.

Companies must have a special toolkit that can help them in determining the agile mindset of its em- ployees. It must help Recruiters in determining the right candidate for the job.

It's important to hire people with an agile mindset for companies which constantly develop their agility. For this situation, Personal Agility Checklist has been compiled based on the main competencies from Agility Health (Tbl. 5) [35].

For the understanding of Personal Agility, Community Agility Health divided the necessary competencies into two domains: individual and social. The individual domain includes the following dimensions: purposefulness, a learning mindset, change orientation; the social domain consists of the empowered, relationship management, collaborative one. To check each competency special questions or exercises were suggested.

In contrast to Hypothesis $\mathbf{3}$, Hypothesis $\mathbf{0}$ has been proposed: Personal Agility can't be checked. It's possible to imagine that determining the agility of a company by business processes is enough. However, it is also important to measure the agility of a person. This process is quite difficult and thus it's not possible to do it in every case, particularly, if there is no special toolkit for checking it.

In such case, Hypothesis 3 has been proved by constructing Personal Agility Checklist. It can help companies already on the stage of the interview to determine the agility of a person.

With the help of developed Toolkit, it's possible to evaluate soft skills of the employee. Personal Agility could be developed by designing events connected with soft skills. Macat Critical Thinking Assessment developed by Macat with the University of Cambridge can be used for checking one of the most important soft skills - critical thinking [37]. Thus, future research must be conducted concerning events to develop agility.

\section{CONCLUSIONS}

Business Agility Journey, which allows determining the state of company maturity and conduct express diagnosis of agility, has been suggested. This Journey is based on the generalization of key business processes at each level of maturity of the company. Also, it allows simplifying the perception and use of Agile Maturity Models as well as to conduct a rapid diagnosis of the maturity level of the company. For the development of the Agile Project Management Journey, the levels of Business Agility Journey from 1 up to 3 were chosen. APM Journey is based on the series of events of the company on the way to Agile Project Management implementation. In its simplicity it allows the company to identify weaknesses on the path to agility as well as identify events for the transition from the traditional to the Agile approach. Agile Project Management Journey has been constructed based on the case studies of the international IT-companies. For the company to be agile, it's also necessary to check employees for agility. The key pillars for the development of the agile mindset have been identified and for assessing the level of Personal Agility a Personal Agility Checklist has been 
Suggested Personal Agility Checklist for PA Competencies

\begin{tabular}{|c|c|c|}
\hline Dimensions & Competency & Personal Agility Checklist (Questions and Exercises) \\
\hline \multirow[t]{3}{*}{ Purposefulness } & 1. Self-led competency & $\begin{array}{l}\text { To check problem-solving skill, it's necessary to ask the candidate } \\
\text { to explain a situation where he/she faced a difficult problem and how } \\
\text { the person dealt with it. } \\
\text { To check stress resistance, it's possible to interrupt the candidate } \\
\text { during his/her speech and ask questions based on the information } \\
\text { which is opposite to what the candidate said before. } \\
\text { To check the time management skill, Recruiter can ask the candidate } \\
\text { a question concerning the planning of his/her day, writing a schedule } \\
\text { and how it is constructed }\end{array}$ \\
\hline & 2. Outcome-oriented person & $\begin{array}{l}\text { Ask the candidate to tell about the time when he/she felt most proud } \\
\text { of him/herself }\end{array}$ \\
\hline & 3. Aligned person & $\begin{array}{l}\text { Tell the applicant about the purpose, vision, and values of the organi- } \\
\text { zation and ask the person about his/her motivation and values }\end{array}$ \\
\hline \multirow{5}{*}{ Learning Mindset } & 1. Systems Thinking & $\begin{array}{l}\text { Ask the candidate what he/she wants to achieve, how the person is } \\
\text { going to achieve it; ask the applicant to tell how he/she quantifies } \\
\text { what was actually achieved. } \\
\text { If there are several candidates, it is possible to conduct Draw How to } \\
\text { Make Toast game [36] }\end{array}$ \\
\hline & 2. Open person & Monitor how the applicant behaves during the interview \\
\hline & 3. Learning Oriented & $\begin{array}{l}\text { Ask the candidate about the time when he/she volunteered for an as- } \\
\text { signment to expand knowledge and skills }\end{array}$ \\
\hline & 4. Resourceful & $\begin{array}{l}\text { Ask such questions as "How can you estimate the elephant's weight } \\
\text { without using the computer?" (IBM) }\end{array}$ \\
\hline & 5. Learnability & $\begin{array}{l}\text { Check marks in the university. Ask the candidate about the problem } \\
\text { situation that happened } 1 \text { year ago, how it was solved and how the } \\
\text { person would solve it now }\end{array}$ \\
\hline \multirow{2}{*}{$\begin{array}{l}\text { Change } \\
\text { Orientation }\end{array}$} & 1. Adaptive person & $\begin{array}{l}\text { Ask the candidate how he/she adjusts to changes that he/she can't } \\
\text { control }\end{array}$ \\
\hline & 2. Resilient person & $\begin{array}{l}\text { Ask the applicant to describe the situation when someone put pres- } \\
\text { sure on him/her }\end{array}$ \\
\hline \multirow{2}{*}{ Empowered } & 1. Supportive environment & $\begin{array}{l}\text { Ask the candidate about the environment he/she prefers to work. Tell } \\
\text { about the company's environment }\end{array}$ \\
\hline & 2. Self-empowered person & $\begin{array}{l}\text { Ask the applicant to describe step by step the process he/she usually } \\
\text { applies for making decision about a plan of actions }\end{array}$ \\
\hline \multirow{3}{*}{$\begin{array}{l}\text { Relationship Man- } \\
\text { agement }\end{array}$} & 1. Networked person & $\begin{array}{l}\text { It's possible to ask the candidate to answer } 16 \text { questions created by } \\
\text { Ryahovsky }\end{array}$ \\
\hline & 2. Impact and influence & $\begin{array}{l}\text { Ask such questions as "What kind of relations between a manager and } \\
\text { his/her subordinates are optimal" }\end{array}$ \\
\hline & $\begin{array}{l}\text { 3. Handles constructive con- } \\
\text { flict }\end{array}$ & $\begin{array}{l}\text { Ask the candidate to provide example of settling disputes between } \\
\text { colleagues at work }\end{array}$ \\
\hline \multirow[t]{3}{*}{ Collaborative } & 1. Team-oriented person & $\begin{array}{l}\text { Ask the applicant to describe a project in which he/she participated. } \\
\text { The person should describe the goals of the team, the number of } \\
\text { people, their role; how long they worked together, what results were } \\
\text { achieved, which responsibilities the candidate chose for him/herself in } \\
\text { view to the initiative. If the person coordinated the team, it's necessary } \\
\text { to know how the work went on, what problems were to be addressed } \\
\text { and how they were solved }\end{array}$ \\
\hline & 2. Cooperative & Ask about his/her relations with team members \\
\hline & 3. Knowledge sharing & $\begin{array}{l}\text { Ask if the person has already participated in some trainings as a coach, } \\
\text { was a mentor for junior specialists or took part in any teaching activity }\end{array}$ \\
\hline
\end{tabular}


constructed. It allows testing of soft skills of employees for the presence of the agile mindset. It is very important for ensuring the successful transition of the company to use the Agile approach in its activities.

\section{LITERATURE}

1. Kharkiv IT Research Report 2019 by PwC and IRS Group // Kharkiv IT Cluster, 2019. URL: https://it-kharkiv.com/ ru/projects/kharkiv-it-research-2019/

2. Zubkova A., Rusanova L. Agile Project Management: Misunderstanding of the Term // Матеріали XI Міжнародної науково-практичної конференції «Проблеми соціально-економічного розвитку підприємств» (м. Харків, 24-26 жовтня 2018 р.). Харків : НТУ «ХП|», 2018.

3. Christopher M. The Agile Supply Chain: Competing in Volatile Markets. Industrial Marketing Management. 2000. Vol. 29. Issue 1. P. 37-44.

DOI: https://doi.org/10.1016/S0019-8501(99)00110-8

4. Benefield G. Rolling out Agile in a Large Enterprise // Proceedings of the 41st Annual Hawaii International Conference on System Sciences (HICSS 2008). IEEE, 2008. URL: http:// agileconsortium.pbworks.com/f/YahooEnterpriseAgile.pdf

5. Patel C., Ramachandran M. Agile Maturity Model (AMM): A Software Process Improvement Framework for Agile Software Development Practices. International Journal of Software Engineering. 2009. Vol. 2. No. 1. P. 3-28.

6. Humble J., Russell R. The Agile Maturity Model Applied to Building and Releasing Software. ThoughtWorks Studios. 2009. URL: https://info.thoughtworks.com/rs/thoughtworks2/images/agile_maturity_model.pdf

7. Warren N. Agile Maturity: How to Cross the Finish Line. August 28, 2019. URL: https://www.outsystems.com/blog/ posts/agile-maturity/

8. Harman Agile Maturity Model. URL: http://info.services.harman.com/rs/378-OMF030/images/Agile_Maturity_Model.PDF

9. Scrum Practitioners. URL: https://www.linkedin.com/ groups $/ 52030$

10. Hoogveld M., Koster J. Measuring the Agility of Omnichannel Operations: An Agile Marketing Maturity Model. International Journal of Economics \& Management Studies. 2016. Vol. 3. No. 6. P. 6-16.

11. Agile Maturity Model-3 different approaches. URL: https://setandbma.wordpress.com/2011/11/30/agile-maturity-model/

12. Qumer A., Henderson-Sellers B., Mcbride T. Agile Adoption and Improvement Model // Proceedings European and Mediterranean Conference on Information Systems 2007 (EMCIS2007) June 24-26, 2007. URL: https://pdfs.semanticscholar.org/e73d/5615ed7b8ebf3b101e229a7bec9a7c1ba651.pdf

13. Packlick J. The Agile Maturity Map a Goal Oriented Approach to Agile Improvement // Agile 2007 (AGILE 2007). IEEE, 2007. P. 266-271. URL: http://citeseerx.ist.psu.edu/viewdoc/download?doi=10.1.1.582.9006\&rep=rep1\&type=pdf

14. Yin A., Figueiredo S., da Silva M. M. Scrum maturity model // Proceedings of the ICSEA. 2011. P. 20-29. URL: https:// pdfs.semanticscholar.org/d66b/95a9d66b91a7d7bde05b6518 f72ad9adda14.pdf?_ga =2.88105051.1723330362.15810088611529751811.1572019745

15. Wikstrand G. The Scrum Maturity Model. URL: http:// www.gregerwikstrand.com/the-scrum-maturity-models/
16. Tousignant D. How Agile are you? Free Agile Maturity Assessment. URL: https://capeprojectmanagement.com/ agile-self-assessment/

17. Team Health Radar Assessment. URL: https://agilityhealthradar.com/team-health-radar-assessment/

18. The Agile Performance Holarchy. URL: https://agilecxo.org/wp-content/uploads/2018/05/APH_model_teaser_ v3.pdf

19. Domains of Business Agility. URL: https://businessagility.institute/learn/domains-of-business-agility/

20. Enterprise Business Agility Model. URL: https://agilityhealthradar.com/enterprise-business-agility-model/

21. Case Study of Yahoo! URL: http://static1.1.sqspcdn. com/static/f/447037/6486321/1270929190703/YahooAgileRollout.pdf

22. Kniberg H. Scrum and XP from the Trenches. URL: http://wwwis.win.tue.nl/2R690/20192020_Q1/doc/ScrumAndXpFromTheTrenchesonline07-31.pdf

23. Case Study of Aniart. URL: https://ain.ua/2019/03/22/ kejs-scrum-aniart/

24. "Millions of Gameloft games are downloaded every day"// Official website of Gameloft. URL: https://www.gameloft. com/en/

25. History and mission // Official website of Sigma Software. URL: https://sigma.software/.

26. For the future // Official website of SoftServe. URL: https://www.softserveinc.com/uk-ua/

27. Who we are // Official website of Dev-Pro.net. URL: https://dev-pro.net/

28. The Consumer Decision Journey. URL: https://www. mckinsey.com/business-functions/marketing-and-sales/ourinsights/the-consumer-decision-journey

29. Townsend W. W. Bond salesmanship. H. Hott and Co., 1924. $468 \mathrm{p}$.

30. Growth Mindset / Business Agility Institute. URL: https://businessagility.institute/learn/growth-mindset/

31. Dr. Deming's 14 Points for Management / The Deming Institute. URL: https://deming.org/explore/fourteen-points

32. Зубкова А. Б. Формування культури якості при впровадженні систем управління якістю. Культура народів Причорномор'я. 2006. № 80. С. 48-54.

33. Зубкова А. Б. Управління організаційною культурою якості продукції на машинобудівному підприємстві : автореф. дис. ... канд.. екон. наук : 08.00.04. Харків, 2010. 20 с.

34. Leybourn E., Hastie Sh. \#noprojects: A Culture of Continuous Value. Iulu.com. 2019. 204 p.

35. Personal Agility Radar. URL: https://workmatters.ie/ wp-content/uploads/2018/08/WorkMatters-Personal-AgilityRadar-Paper.pdf

36. Draw How to Make Toast. URL: https://www.drawtoast.com/

37. Macat CriticalThinking Assessments. URL: https://static1.squarespace.com/static/59b7cd299f74569a3aaf0496/t/5a b8f6d08a922dbfc6cd91e5/1522071254588/Tests+brochure++employers.pdf

\section{REFERENCES}

"Agile Maturity Model-3 different approaches". https:// setandbma.wordpress.com/2011/11/30/agile-maturity-model/

Benefield, G. "Rolling out Agile in a Large Enterprise". Proceedings of the $41^{\text {st }}$ Annual Hawaii International Conference on 
System Sciences (HICSS 2008). IEEE, 2008. http://agileconsortium.pbworks.com/f/YahooEnterpriseAgile.pdf

Christopher, M. "The Agile Supply Chain: Competing in Volatile Markets". Industrial Marketing Management, vol. 29, no. 1 (2000): 37-44.

DOI: https://doi.org/10.1016/S0019-8501(99)00110-8

Case Study of Aniart. https://ain.ua/2019/03/22/kejsscrum-aniart/

Case Study of Yahoo! http://static1.1.sqspcdn.com/static/f/447037/6486321/1270929190703/YahooAgileRollout.pdf

"Dr. Deming's 14 Points for Management". The Deming Institute. https://deming.org/explore/fourteen-points

"Draw How to Make Toast". https://www.drawtoast.com/ Domains of Business Agility. https://businessagility.institute/learn/domains-of-business-agility/

Enterprise Business Agility Model. https://agilityhealthradar.com/enterprise-business-agility-model/

"For the future". Official website of SoftServe. https:// www.softserveinc.com/uk-ua/

"Growth Mindset". Business Agility Institute. https://businessagility.institute/learn/growth-mindset/

"History and mission". Official website of Sigma Software. https://sigma.software/

Harman Agile Maturity Model. http://info.services.harman.com/rs/378-OMF030/images/Agile_Maturity_Model.PDF

Hoogveld, M., and Koster, J. "Measuring the Agility of Omnichannel Operations: An Agile Marketing Maturity Model". International Journal of Economics \& Management Studies, vol. 3, no. 6 (2016): 6-16.

Humble, J., and Russell, R. "The Agile Maturity Model Applied to Building and Releasing Software". Thought Works Studios. 2009. https://info.thoughtworks.com/rs/thoughtworks2/ images/agile_maturity_model.pdf

"Kharkiv IT Research Report 2019 by PwC and IRS Group". Kharkiv IT Cluster, 2019. https://it-kharkiv.com/ru/projects/ kharkiv-it-research-2019/

Kniberg, H. "Scrum and XP from the Trenches". http:// wwwis.win.tue.nl/2R690/20192020_Q1/doc/ScrumAndXpFromTheTrenchesonline07-31.pdf

Leybourn, E., and Hastie, Sh. \#noprojects: A Culture of Continuous Value. lulu.com., 2019.

"Macat Critical Thinking Assessments". https://static1. squarespace.com/static/59b7cd299f74569a3aaf0496/t/5ab8 f6d08a922dbfc6cd91e5/1522071254588/Tests+brochure++employers.pdf

"Millions of Gameloft games are downloaded every day". Official website of Gameloft. https://www.gameloft.com/en/

Packlick, J. "The Agile Maturity Map a Goal Oriented Approach to Agile Improvement". Agile 2007 (AGILE 2007). IEEE, 2007. http://citeseerx.ist.psu.edu/viewdoc/download?doi=10. 1.1.582.9006\&rep=rep1\&type=pdf
Patel, C., and Ramachandran, M. "Agile Maturity Model (AMM): A Software Process Improvement Framework for Agile Software Development Practices". International Journal of Software Engineering, vol. 2, no. 1 (2009): 3-28.

Personal Agility Radar. https://workmatters.ie/wp-content/uploads/2018/08/WorkMatters-Personal-Agility-RadarPaper.pdf

Qumer, A., Henderson-Sellers, B., and Mcbride, T. "Agile Adoption and Improvement Model". Proceedings European and Mediterranean Conference on Information Systems 2007 (EMCIS2007) June 24-26, 2007. https://pdfs.semanticscholar. org/e73d/5615ed7b8ebf3b101e229a7bec9a7c1ba651.pdf

Scrum Practitioners. https://www.linkedin.com/groups/ 52030

"Team Health Radar Assessment". https://agilityhealthradar.com/team-health-radar-assessment/

"The Agile Performance Holarchy". https://agilecxo.org/ wp-content/uploads/2018/05/APH_model_teaser_v3.pdf

The Consumer Decision Journey. https://www.mckinsey. com/business-functions/marketing-and-sales/our-insights/ the-consumer-decision-journey

Tousignant, D. "How Agile are you? Free Agile Maturity Assessment". https://capeprojectmanagement.com/agile-selfassessment/

Townsend, W. W. Bond salesmanship. H. Hott and Co., 1924.

"Who we are". Official website of Dev-Pro.net. https:// dev-pro.net/

Warren, N. "Agile Maturity: How to Cross the Finish Line". August 28, 2019. https://www.outsystems.com/blog/posts/ agile-maturity/

Wikstrand, G. "The Scrum Maturity Model". http://www. gregerwikstrand.com/the-scrum-maturity-models/

Yin, A., Figueiredo, S., and da Silva, M. M. "Scrum maturity model". Proceedings of the ICSEA. 2011. https://pdfs. semanticscholar.org/d66b/95a9d66b91a7d7bde05b6518f72 ad9adda14.pdf?_ga=2.88105051.1723330362.15810088611529751811.1572019745

Zubkova, A. B. "Formuvannia kultury yakosti pry vprovadzhenni system upravlinnia yakistiu" [Formation of a Culture of Quality in the Implementation of Quality Management Systems]. Kultura narodiv Prychornomoria, no. 80 (2006): 48-54.

Zubkova, A. B. "Upravlinnia orhanizatsiinoiu kulturoiu yakosti produktsii na mashynobudivnomu pidpryiemstvi" [Management of Organizational Culture of Product Quality at the Machine-building Enterprise]: avtoref. dys. ... kand. . ekon. nauk :08.00.04, 2010.

Zubkova, A., and Rusanova, L. "Agile Project Management: Misunderstanding of the Term". Problemy sotsialno-ekonomichnoho rozvytku pidpryiemstv. Kharkiv: NTU «KhPl», 2018. 